\title{
Water Usage Patterns and Water Saving Devices in Households: A Case of Eastleigh, Nairobi
}

\author{
Muhammad Ali1 ${ }^{*}$, Geryyshom Munala1, Teckla Muhoro1, James Shikuku1, \\ Victor Nyakundi ${ }^{1}$, Andrew Gremley ${ }^{2}$ \\ ${ }^{1}$ Center for Urban Studies, Jomo Kenyatta University of Agriculture and Technology, Nairobi, Kenya \\ ${ }^{2}$ Pharos Architects, Nairobi, Kenya \\ Email: *muhammad.ali@jkuat.ac.ke
}

How to cite this paper: Ali, M., Munala, G., Muhoro, T., Shikuku, J., Nyakundi, V. and Gremley, A. (2020) Water Usage Patterns and Water Saving Devices in Households: A Case of Eastleigh, Nairobi. Journal of Water Resource and Protection, 12, 303-315.

https://doi.org/10.4236/jwarp.2020.124018

Received: March 4, 2020

Accepted: April 6, 2020

Published: April 9, 2020

Copyright $\odot 2020$ by author(s) and Scientific Research Publishing Inc. This work is licensed under the Creative Commons Attribution International License (CC BY 4.0).

http://creativecommons.org/licenses/by/4.0/

(c) (i) Open Access

\begin{abstract}
Water conservation measures are rapidly becoming a necessity in urban environments all over Africa and the world. There is little innovation and available information for homeowners, building professionals and practitioners to guide towards water conservation. Water scarcity has progressively increased over periods of time in Eastleigh due to increased population density from increased high-rise apartments. The study tries to establish how water usage patterns and water conservation devices can potentially reduce water consumption levels. In the study area, $96 \%$ of the families are faced with problems related to water supply and hence are forced to come up with water conservation and adaptation strategies due to the scarcity of water. The study used survey and descriptive research design, and collected data on water usage patterns and water conservation devices from a total of 230 households in Biafra and Sewage estates in the Eastleigh neighbourhood. The results indicated that $76 \%$ of the households did not have water saving devices while the other $24 \%$ had water saving devices such as the dual flush toilets, low flow high-efficiency faucet aerators, low flow plumbing fixtures and automatic shut-off nozzles. A unit increase in water saving devices will lead to a 0.512 decrease in water consumption level. The study recommends that low-income households use water saving devices and develop water management strategies such as water-saving plumbing fixtures, rainwater harvesting, and grey water reuse.
\end{abstract}

\section{Keywords}

Water Saving Devices, Water Usage patterns, Nairobi 


\section{Introduction}

Developing efficient strategies to reduce water consumption is linked to the characterization of water end-uses. From this knowledge it is possible to evaluate the main devices responsible for water [1]. To date, water-saving has been the subject of research and patents. The increase in urban water users as reported by [2] and the per capita growth in water consumption of urban residents [3] all lead to substantial increases in water demand. In 2012, 40\% of the world's population suffered water shortage problems, and most cities in the world were seeking a more efficient management of water resources to relieve water scarcity issues [4].

Water Saving Devices sustain demands for potable water, soften impacts on supply systems and have a positive effect on wastewater treatment systems [2]. Water scarcity is one of the most challenging issues in the world [3]. Demand for potable water is rising because of factors such as the increase in population, improvements in living standards, and increased protection of surrounding ecosystems [5]. As reported by [6] that aerators (taps with air devices) and taps with thermostats could save up to $50 \%$ water, those equipped with infrared sensors could save up to $80 \%$. Devices that limit shower flow could lead to water savings of $10 \%-40 \%$. Toilets are the biggest water-guzzling appliances in homes (13 - 16 liters per flush).

With the development of new public housing policies, the rational use of water in low-income houses has the potential to reduce demand on public water systems and sewage. Thus, the characterization of water consumption in these dwellings can be an important step to promote potable water savings at the urban scale [7].

Water conservation campaigns have often been presented in terms of averages. However, as explained by [8] customised feedback can provide a more accurate basis for assessment and action, thereby enabling progress towards a (conservation) goal. Therefore, disaggregated water-use feedback may promote conservation at the individual and household levels. Many developers and homeowners have installed systems that attempt to address the problems of water consumption and drinking water including rainwater collection tanks, but most of the systems installed are highly ineffective due to poor design or require tedious and impractical user involvement [9].

\section{Water Usage Patterns}

Water usage pattern refers to the way water is used within a given household during different times. In this regard, various past studies by [10] have established that water usage during the day is higher compared to night times. This has been attributed to the fact that there are many water consumption activities during the day such as laundry, car wash, house cleaning, among others, compared to night times [10]. Residential dwellings are considered to be moderate water consumers overall, in comparison to commercial buildings and institu- 
tions since they are normally hold only a few individuals [10].

The water consumption trends are explained by linking the different types of housing, the socio-economic factors, and demand and supply of houses. When different levels of drinking water consumption are analysed, it should be taken into account that there is a very broad range of building types in the city [11]. Thus, different systems and devices should be taken into consideration depending on the number of people in a household.

Water demand management on the other hand focuses on key social and economic characteristics that may influence domestic water use [12]. Understanding both water use and consumption is critical to evaluating water stress on the municipality. As reported by [13] water consumption estimates, on the other hand, help gauge the impact of water use on downstream water availability and are essential to evaluating water shortages and scarcity at the watershed level, including impacts on aquatic ecosystems [14]. Therefore, a holistic understanding of water stress requires analysis of both the amount of water used from the sources and the domestic consumption.

Decisions regarding the most appropriate level at which to manage different aspects of water service delivery need to be based on a realistic assessment of existing capacity and resources, rather than idealized models of democratic decentralization [15]. The pressure on limited water resources is likely to intensify in the future. The global population is expected to reach 9.6 billion by 2050 , adding over 2 billion mouths to feed to the current population [9]. The water consumption patterns place the most pressure on the world's diminishing freshwater resources [16], households can also make a significant contribution in reducing overall water demands.

On a global scale, most domestic water consuming activities are related to hygiene purposes such as showering, bathing, toilets, and washing machines [14]. Watering lawns and gardens is a water-demanding activity too, particularly in warm and dry conditions [11]. In the face of rapid urbanisation, climate change, and increasing affluence [17], water crises such as Australia's struggle with the millennium droughts or Cape Town's 2018 threat of day zero, when supplies would be fully depleted, are likely to unfold more frequently, with far-reaching consequences. In parallel, supply side technologies such as waste water recycling and the use of alternative sources (e.g. rainwater harvesting and desalination) are increasingly viewed as necessary measures [15].

\section{Water Saving Devices}

Developing efficient strategies to reduce water consumption is linked to the characterization of water end-uses. From this it is possible to evaluate the main devices responsible for water use and prioritize the development of technologies to generate more effective water savings [1]. A survey carried out in 1188 households in the United States and Canada verified the consumption and water end-uses for a period of three years. It was noticed that more than half of the 
consumption of the surveyed households (58\% of total consumption) was used in external activities. As for the domestic consumption in homes with conventional water fixtures, the highest consumption was found for toilets (76.1 $\mathrm{L} /$ capita.day), followed by washing machines ( $56.8 \mathrm{~L} /$ capita.day) and showers (50.3 L/capita-day). In homes with water saving appliances, washing machines had the highest consumption (56.8 L/capita.day), followed by taps (41.3 $\mathrm{L} /$ capita.day), showers (37.9 L/capita.day), and toilet flushing (36.3 L/capita.day) [18].

\section{Equipments/fixtures to conserve water}

As reported by [19] analysed the amount of water used by all possible appliances in single-family households from different municipalities in the US and Canada. Their results show that households with low-flow shower-heads increase their shower times. [14] estimated a reduction in water use of about 3.5\% due to a regulation imposing the installation of low-flow fixtures and devices in Arizona. However, they found increases of about $3.8 \%$ to $4.6 \%$ in water use after the installation of free retrofit device kits. In contrast, water savings of between $2.4 \%$ and $6.4 \%$ were achieved from the installation of similar devices after personal in-house visits with person-to-person communication.

As reported by [6], from research in North Carolina, USA, water savings attributable to the rebate program were less than one-half the expected savings associated with that installation of water saving devices such as aerators. [20] uses data from a field trial, in which randomly selected households received high-efficiency washing machines free of charge. Households increased the use of washing machines by $5.6 \%$ on average after obtaining the high-efficiency appliance, that is, part of the efficiency gains were offset by increased usage.

[21] also showed that water savings obtained by using efficient water-using technologies may differ depending on the kind of device or appliance analysed. Households may invest in a particular efficient appliance or demonstrate a specific water conservation habit because of the resulting energy savings rather than the decrease in water use, due to the lower relative price of water versus the price of energy. Thus, aggregate indices such as those found in [21] may not fully capture the relationship between efficient water-using technologies and habits, and their respective determinants. Based on the aspects of water-saving, three strategies are summarized, as illustrated in Figure 1, according to [21].

\section{Methodology}

A descriptive research design was used with a research survey undertaken for water usage patterns and conservation methods in the study areas of Biafra estate and Sewage estate in the Eastleigh neighborhood in Nairobi County. Questionnaires, observation checklists and interview guides were used. 230 questionnaires were distributed to the households in which the questionnaire was designed to get information on the water saving devices, knowledge about water saving devices and willingness to install water saving devices in the households, and other related information concerning water usage patterns. Through simple 


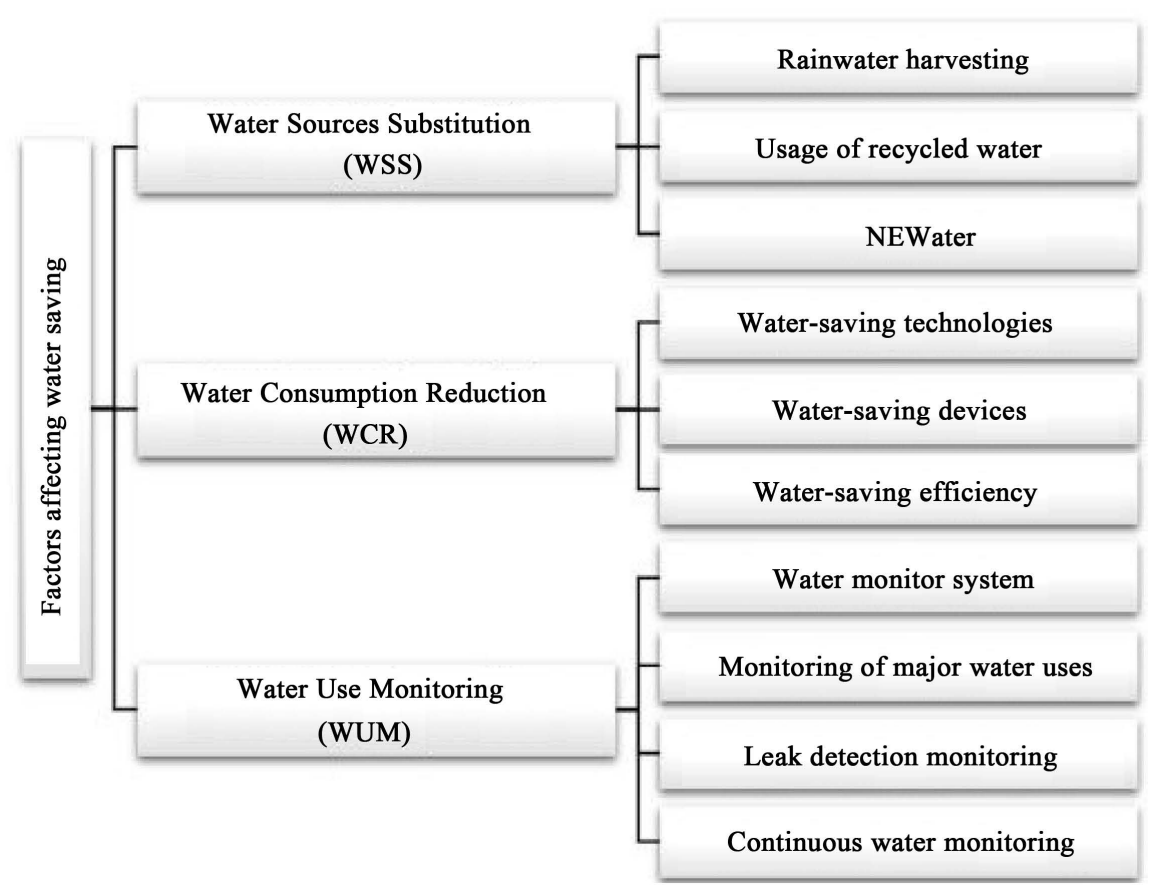

Figure 1. Factors affecting water saving source: Developing a strategic framework for adopting water-saving measures in construction projects [21].

random sampling, a sample size of 100 households was established in Biafra Estate. The households of the neighborhood were of the same layout but have various socio-economic status, nevertheless, a good representation was obtained for the whole study area. Stratified probability sampling was used in Sewage Estate as the area had different house layouts with 130 households being sampled. The second part of the study was carried out by use of interview guides by visiting seven local hardware shops, two of which were in the Biafra estate, four in the Sewage Estate, while one was located neighbouring the study area to find out water fixtures that were being sold and their availability in the different hardware stores.

\section{Study Area}

This study was carried out in Nairobi County $\left(-1.286648^{\circ} \mathrm{S}, 36.851048^{\circ} \mathrm{E}\right)$ in Biafra and Sewage Estates in Eastleigh, Kamukunji Sub County in Nairobi, Kenya. It is located approximately $11 \mathrm{~km}$ from the City Centre and measures approximately 60 hectares. The two estates are separated by a $15 \mathrm{~m}$ wide road known as Eastleigh First Avenue, accessed through Jogoo Road and General Wariunge Street as shown in Figure 2.

The study areas are situated in the middle of the Eastlands of Nairobi, which are characterized by overcrowding settlements that exert a lot of pressure on the water supplied by Nairobi City Water and Sewerage Company. This leads to severe water shortages with water rationing as many times as $3-5$ days in a week. Hence, residents in these areas have turned to water storage tanks, water vendors and illegal connections as sources of water as shown in Figure 3. 


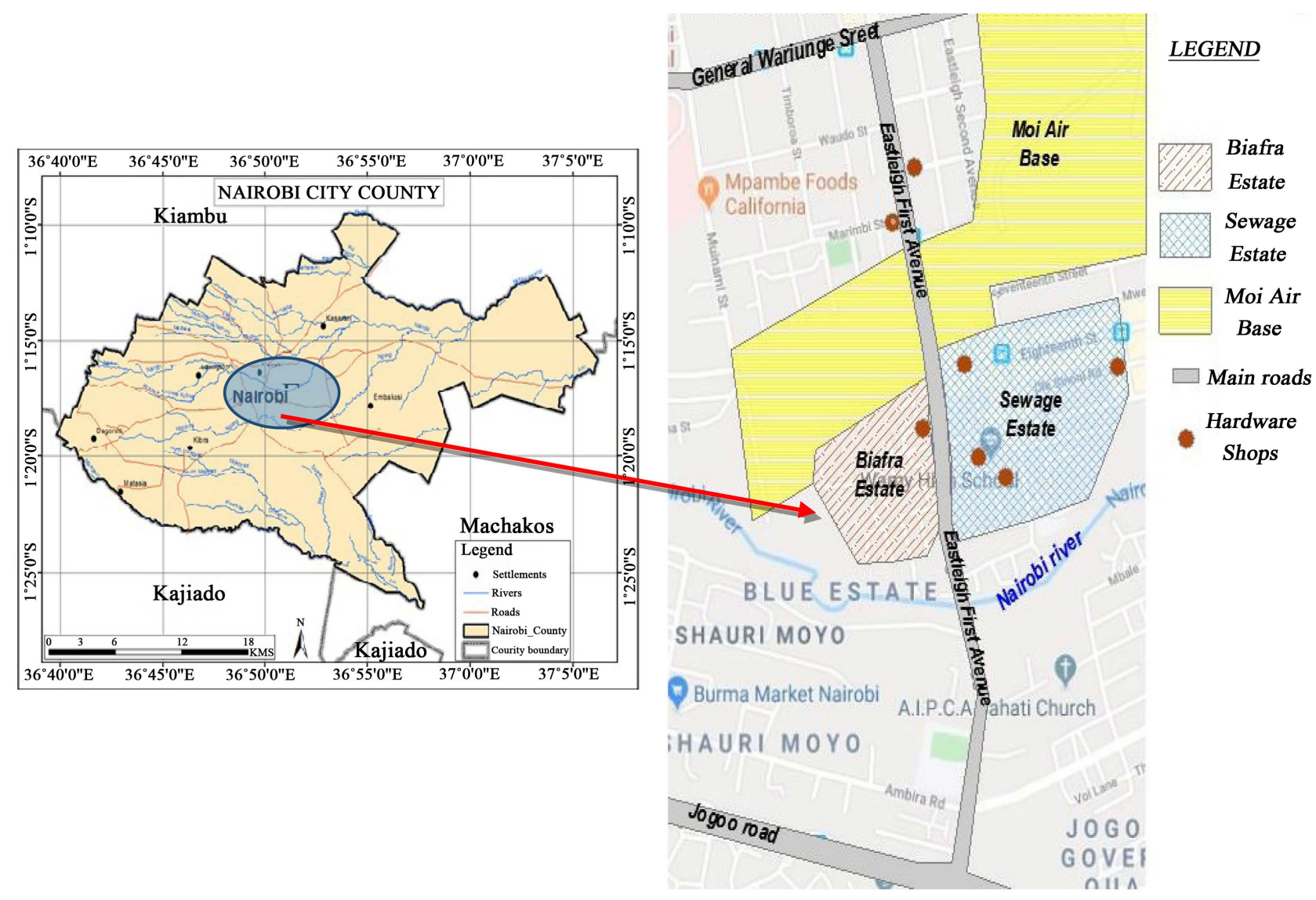

Figure 2. Showing the study area Eastleigh in Nairobi County. Source: Google Maps, modified by Author.
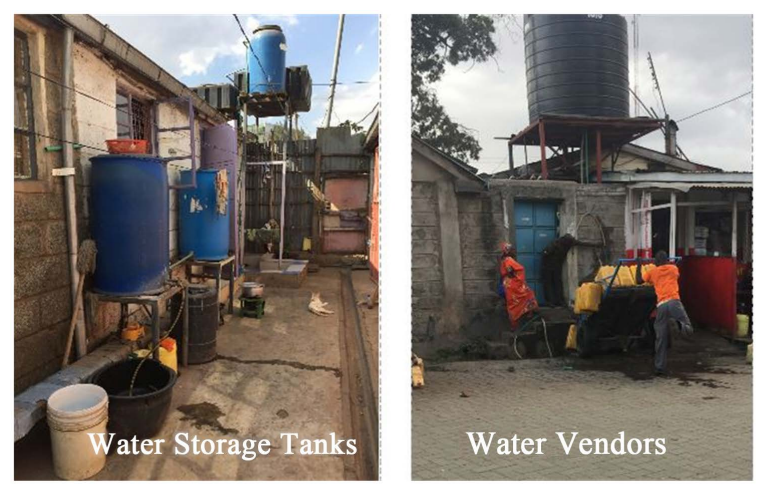

Figure 3. Water storage tanks and water vendors as sources of water.

\section{Results and Analysis}

\subsection{Water Usage Patterns}

The knowledge of water usage patterns in terms of the end uses in dwellings is key for water planning. The water end-uses are useful in order to evaluate actions to reduce water demand and waste generated in households, as well as possible alternative sources of water [22]. The study established the different sizes of households as this was critical in determining the amount of water usage. It was revealed that, in Biafra $57 \%$ of the household consisted of more than five 
people, $20 \%$ consisted of four people, and $16 \%$ consisted of three people, while $7 \%$ consisted of two people or less than two people as shown in Figure 4. Water end-uses are also essential to identify the portion of total demand that can be saved through alternative sources of water [22].

According to the guidelines for drinking-water quality mentioned in Volume 3 of the publication surveillance and control of community supplies by [23], a minimum of 15 litres per capita per day is required. A higher quantity of about 20 litres per capita per day which was noted in some households should be assured to take care of basic hygiene needs and basic food hygiene. Laundry and bathing might require higher amounts, unless carried out at the source.

\subsection{Household Water Uses}

In Biafra, $52 \%$ of water usage inside the house is for washing, $34 \%$ for bathing, $4 \%$ for toilet, $6 \%$ for cooking and $4 \%$ for drinking. In Sewage, it was found that $58 \%$ of the water usage inside the house is for washing, $29 \%$ for toilet, $5 \%$ for bathing, $8 \%$ for cooking and 10\% for drinking, as shown in Figure 5. Washing was consuming most water in the house, while drinking the least.

The study also sought to establish household water usage outside the house and it was revealed that in Biafra estate $60 \%$ of water usage outside the house was for car wash, $35 \%$ for washing verandas and $5 \%$ for watering the lawn, while in Sewage estate, $53 \%$ of outside-of-the house water consumption was for car wash and $2 \%$ for watering the lawn, as the study area had only few houses with lawns, as shown in Figure 6.

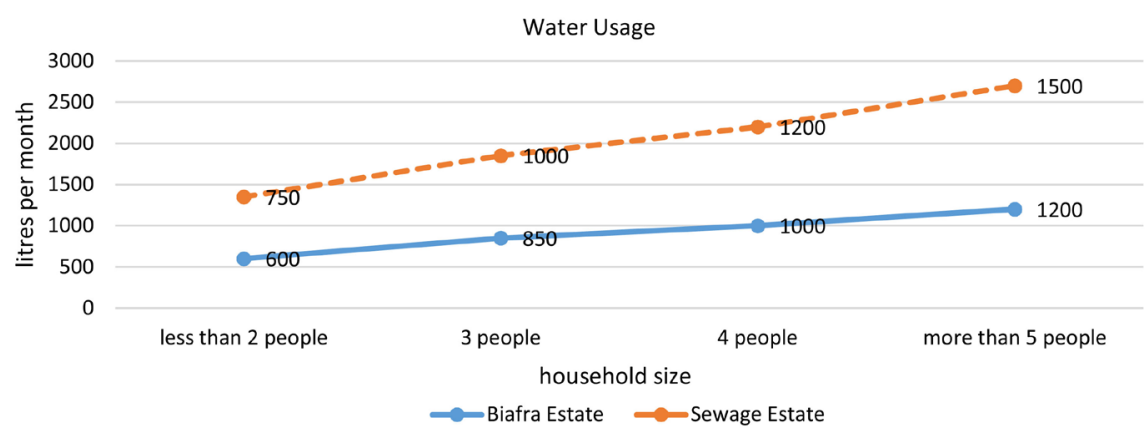

Figure 4. Showing water usage in different types of households.

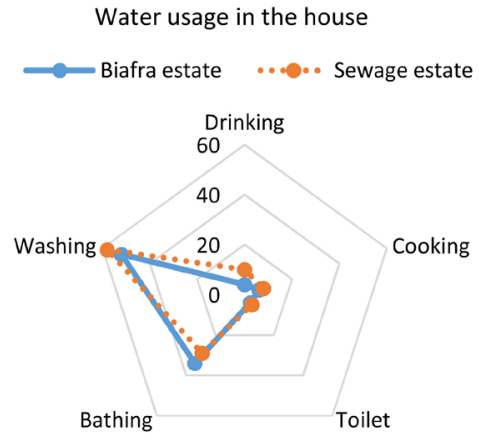

Figure 5. Distribution of water uses inside the house. 


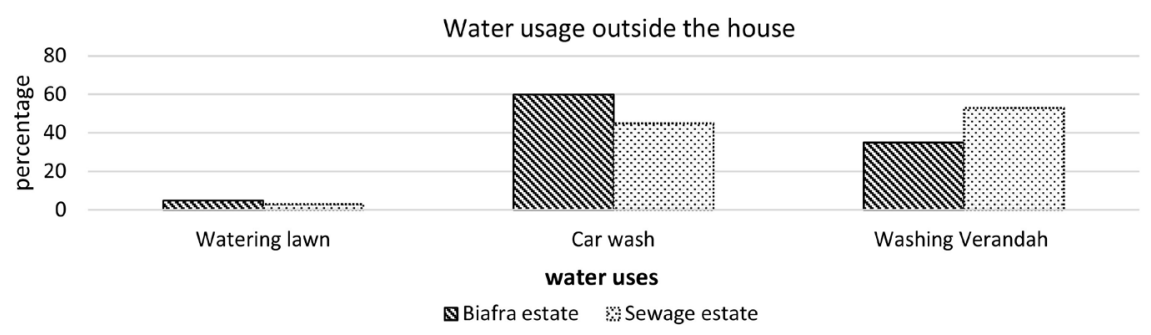

Figure 6. Distribution of household water uses outside the house.

\subsection{Water Consumption and Water Reliability}

The daily water consumption per person in a household in the study areas was investigated so as to account for water usage and what devices can help in reducing the water usage per person. The study results established that in Biafra, $45 \%$ of households' per person average daily water consumption is 20 - 50 litres, In Sewage, it was found out that $52 \%$ of the households' per person daily water consumption is less than 20 litres, The study found out that no single person in Sewage estate was found to consume more than 100 litres of water per day as shown in Figure 7.

It was also established that $75 \%$ of the respondents from Biafra and Sewage estates indicated that they normally experience water rationing, while $25 \%$ indicated that they do not experience water rationing. The study looked at the aspect of water reliability and found out that $49 \%$ of respondents indicated that they receive county connected water three days a week, $31 \%$ four days a week, $14 \%$ less than two days a week, while $6 \%$ receive county water for more than five days a week as shown in Figure 8.

\subsection{Current Water-Conservation Techniques and Devices}

In the Eastleigh neighborhood, $73.7 \%$ of respondents engaged in at least one water conservation technique. $84 \%$ of the households reported in engaging in the conservation behavior of turning the faucet off when brushing teeth or washing dishes. Water-conservation techniques that require some level of effort but no financial cost, such as reusing wastewater from filtration systems, were at $16 \%$. A total of $73.7 \%$ of participants reported having some form of water-treatment system at home for treating drinking water.

The study also found out that $78 \%$ of residents reported reusing waste water in various ways: watering plants, mopping, laundry, and flushing toilets. Conservation technology, which requires financial costs but no added effort after installation, is less popular than measures that require effort but no financial costs. Only $36 \%$ of households interviewed had installed water-conserving dual flush toilets. Of those participants who answered about why they had installed dual flush toilet systems, $32 \%$ said they had installed them to conserve water, $35 \%$ said they did so based on advice, and 33\% said they had installed them during renovations, because it was a new technology. Many participants were not familiar with the technology at all. The following behaviors can help conserve 


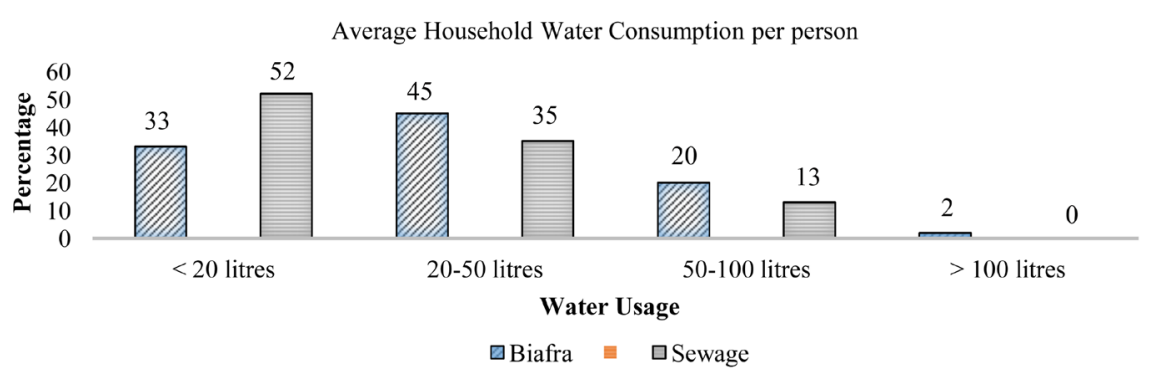

Figure 7. Average household water consumption per person.

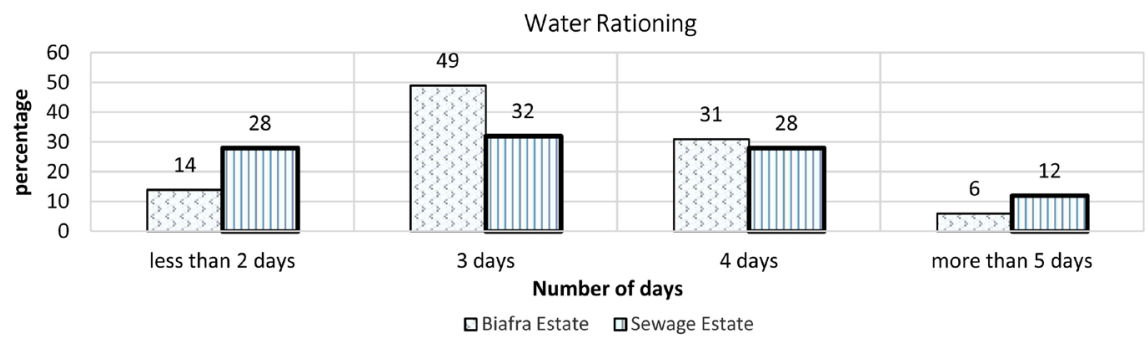

Figure 8. Percentages of water rationing.

water by reducing the amount of water a person uses and save money too: turning the water off during brushing teeth; turning off the tap while washing vegetables; turning the shower off while soaping in; starting the washing machine only when it is full to save water, and repairing leaks or reporting them to landlords [21].

\subsubsection{Devices to Minimize Water Usage}

The findings of this study have several implications for residential water usage in Kenya and the developing world. However, the results from this study suggest that households having limited supplies of water (those that received less than three days of water supply per week and those that supplement their municipal supply with water from an alternate source) were having water storage tanks as storage facilities. Yet, these households were actually engaging in water conservation techniques and devices less frequently than the average respondent.

It was found out that $76 \%$ of respondents did not have water saving devices, while $24 \%$ had devices that reduced water usage in their houses. In addition, respondents who indicated that they had water saving devices in their houses named the following as the devices they had in place: low flow high-efficiency faucet aerators (7\% in Biafra estate and 19\% in Sewage estate), low flow plumbing fixtures ( $2 \%$ in Biafra estate and $28 \%$ in Sewage estate), dual flush toilets (32\% in Biafra estate and $49 \%$ in Sewage estate), and automatic shut-off nozzles taps (6\% in Biafra estate and $12 \%$ in Sewage estate).

On the other hand, the study suggests that water saving devices such as aerators, dual flush toilets may be effective in encouraging water-conservation behaviour. Nevertheless, survey responses indicated that $64 \%$ of the participants were unconcerned with water saving devices and techniques, and thus ended up 


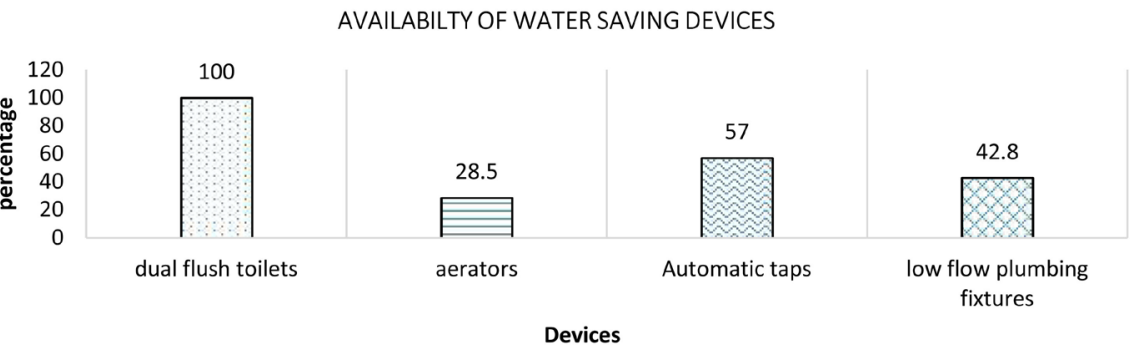

Figure 9. Availability of water-saving devices.

consuming more water.

\subsubsection{Willingness to Purchase Water Reduction Gadgets}

In Eastleigh neighborhood $72 \%$ of respondents indicated that they were willing to buy appliances/gadgets that could help them reduce water usage, while $28 \%$ indicated that they could not buy them. Out of the $28 \%, 46 \%$ of respondents indicated that they could not buy appliances/gadgets to help them reduce water usage because they are expensive, 30\% indicated that these gadgets/appliances are not easily found, while $18 \%$ indicated that these appliances/gadgets are both expensive and also not easy to find while the remaining $6 \%$ said they do not have the knowledge of water saving devices.

The effectiveness of water-saving can be gauged intuitively by water-saving devices and practices, as it is easy to enhance the residents' awareness of water-saving and encourage them to increase water-saving. [24] indicated that in North Carolina, USA, social information and appeals to norm-based behaviour reduce water use by up to $6.8 \%$ in households directly targeted by the campaign and households that were not targeted by the campaign reduced water use by $5.8 \%$ in the first 6 months following the intervention.

\subsubsection{Availability of the Devices}

Seven hardware shops within the study area were visited to check on the availability of the devices which could help in saving water by reducing the amount of water usage. Of the shops, $100 \%$ had dual flush toilets, while $28.5 \%$ had aerators, $57 \%$ had automatic shut off taps and $42.8 \%$ had low flow plumbing fixtures with them as depicted in Figure 9.

\section{Conclusions}

This study sought to investigate patterns and practices in water usage and conservation in Eastleigh neighbourhood and to explore with the influence of water saving devices. The study found out that water saving devices such as aerators, dual flush toilets may be effective in encouraging water-conservation behaviour, however, with $64 \%$ of the participants unconcerned with water saving devices and techniques thus ending up consuming more water. These results indicate a lack of proper water saving practices together with a lack of water saving devices being used leading to more water consumption. Thus, a local awareness to the 
home owners and developers on water-conservation practices in terms of techniques and devices will be a potential way to encourage water-conservation, by demonstrating that the households have invested in improving water conservation. Educational campaigns that teach easy ways to conserve water may increase awareness, and this study indicates awareness correlates with a willingness to reduce water consumption in the households as increasing usage of water saving devices leads to a decrease in water consumption level.

The results of this study can be used to develop integrated water management strategies, e.g. water-saving plumbing fixtures, rainwater harvesting, and grey-water reuse, in low income developments in Eastlands. Knowledge about water consumption patterns is key for awareness campaigns about water conservation practices among households.

\section{Acknowledgements}

The author would like to express his appreciation to all the consultants who funded this research through the lead of Pharos Architects ltd, Water Conservation Fellowship.

\section{Conflicts of Interest}

The authors declare no conflicts of interest regarding the publication of this paper.

\section{References}

[1] Rocha, A.L., Barreto, D., Ioshimoto, E. and Caracterização e monitoramento do consumo predial de água (1998) Water Consumption Assessment and Monitoring in Building). National Programme to Combat Wasting Water-Technical Support Document. Ministério do Planejamento e Orçamento, Brasília, Brazil. (In Portuguese)

[2] Eckert, S. and Kohler, S. (2014) Urbanization and Health in Developing Countries: A Systematic Review. World Health \& Population, 15, 7-20. https://doi.org/10.12927/whp.2014.23722

[3] Wu, P. and Tan, M. (2012) Challenges for Sustainable Urbanization: A Case Study of Water Shortage and Water Environment Changes in Shandong, China. Procedia Environmental Sciences, 13, 919-927. https://doi.org/10.1016/j.proenv.2012.01.085

[4] Fahs, H., Hayek, M., Fahs, M. and Younes, A. (2013) An Efficient Numerical Model for Hydrodynamic Parameterization in 2D Fractured Dual-Porosity Media. Advances in Water Resources, 63, 179-193. https://doi.org/10.1016/j.advwatres.2013.11.008

[5] Bao, C. and Fang, C.-L. (2011) Water Resources Flows Related to Urbanization in China: Challenges and Perspectives for Water Management and Urban Development. Water Resource Management, 26, 531-552. https://doi.org/10.1007/s11269-011-9930-y

[6] Lallana, E.A. (2001) Industrial Water Demand Management and Cleaner Production Potential: A Case Study of Three Industries in Bulawayo, Zimbabwe.

[7] Cohim, E., Garcia, A.P.A., Kiperstok, A., Dias, M. and Consumo de água em Residências de Baixa Renda-Estudo de Caso (2009) Water Consumption in Low-Income 
Households-A Case Study; $25^{\circ}$ Congresso Brasileiro de Engenharia Sanitária e Ambiental, Recife, Brazil. (In Portuguese)

[8] Aitken, C.K., McMahon, A., Wearing, A.J. and Finlayson, B.L. (1994) Residential Water Use: Predicting and Reducing Consumption. Journal of Applied Social Psychology, 24, 136-158. https://doi.org/10.1111/j.1559-1816.1994.tb00562.x

[9] UN-Water (2007) Coping with Water Scarcity: Challenges of the Twenty First Century. FAO. http://www.un.org/waterforlifedecade/scarcity.shtml

[10] Fikru, M.G. and Gautier, L. (2015) The Impact of Weather Variation on Energy Consumption in Residential Houses. Applied Energy, 144, 19-30.

https://doi.org/10.1016/j.apenergy.2015.01.040

[11] March, H. and Saurí, D. (2009) What Lies behind Domestic Water Use? A Review Essay on the Drivers of Domestic Water Consumption. Boletín de la Asociación de Geógrafos Españoles, 50, 297-314.

[12] Garcia, B.A. and Cortes, M.P. (1989) Final Report of Project UE-9003, Mexican Institute of Water Technology, Cuernavaca, Morelos, Mexico.

[13] Ywashima, L.A., Campos, M.A.S., Piaia, E., Luca, D.M.P. and Ilha, M.S.O. (2006) Caracterização do uso de água em residências de interesse social em Paulínia (Water Consumption Assessment in Low-Income Houses in Paulínia). In: Proceedings of the XI Encontro Nacional de Tecnologia do Ambiente Construído, Florianópolis-SC, Brazil. (In Portuguese)

[14] Campbell, H.E., Johnson, R.M. and Larson, E.H. (2004) Prices, Devices, People, or Rules: The Relative Effectiveness of Policy Instruments in Water Conservation. Review of Policy Research, 21, 637-662. https://doi.org/10.1111/j.1541-1338.2004.00099.x

[15] Steflova, M., Koop, S., Elelman, R., Vinyoles, J. and Van Leeuwen, K. (2018) Governing Non Potable Water-Reuse to Alleviate Water Stress: The Case of Sabadell, Spain. Water, 10, 739. https://doi.org/10.3390/w10060739

[16] Hoekstra, A.Y., Mekonnen, M.M., Chapagain, A.K., Mathews, R.E. and Richter, B.D. (2012) Global Monthly Water Scarcity: Blue Water Footprints versus Blue Water Availability. PLoS ONE, 7, Article ID: 32688 https://doi.org/10.1371/journal.pone.0032688

[17] Koop, S.H.A. and Van Leeuwen, C.J. (2017) The Challenges of Water, Waste and Climate Change in Cities. Environment, Development and Sustainability, 19, 385-418. https://doi.org/10.1007/s10668-016-9760-4

[18] Mayer, P.W., De Oreo, W.B., Opitz, E.M., Kiefer, J.C., Davis, W.Y., Dziegielewski, B. and Nelson, J.O. (1999) Residential End Uses of Water. Version 2. AWWA Research Foundation and American Water Works Association, Denver, CO.

[19] Mayer, P.W., De Oreo, W.B., Opitz, E.M., Kiefer, J.C., Davis, W.Y., Dziegielewski, B. and Nelson, J.O. (1998) Residential End Uses of Water. American Water Work Association Research Foundation, Denver, CO.

[20] Davis, L.W. (2008) Durable Goods and Residential Demand for Energy and Water: Evidence from a Field Trial. RAND Journal of Economics, 39, 530-546. https://doi.org/10.1111/j.0741-6261.2008.00026.x

[21] Marinho, M., do Socorro Gonçalves, M. and Kiperstok, A. (2014) Water Conservation as a Tool to Support Sustainable Practices in a Brazilian Public University. Journal of Cleaner Production, 62, 98-106. https://doi.org/10.1016/j.jclepro.2013.06.053

[22] Willis, R.M., Stewart, R.A., Giurco, D.P., Talebpour, M.R. and Mousavinejad, A. 
(2013) End Use water Consumption in Households: Impact of Socio-Demographic Factors and Efficient Devices. Journal of Cleaner Production, 60, 107-115.

https://doi.org/10.1016/j.jclepro.2011.08.006

[23] WHO (1997) Guidelines for Drinking-Water Quality, Volume 3, Surveillance and Control of Community Supplies. Guidelines for Drinking-Water Quality II WHO Library Cataloguing in Publication Data. 2nd Edition, World Health Organization, Geneva, 1-250.

[24] Torres, M.M.J. and Carlsson, F. (2018) Direct and Spill over Effects of a Social Information Campaign on Residential Water-Savings. Journal of Environmental Economics and Management, 92, 222-243. https://doi.org/10.1016/j.jeem.2018.08.005 